University of Nebraska - Lincoln

DigitalCommons@University of Nebraska - Lincoln

Faculty Publications from the Harold W. Manter Laboratory of Parasitology

6-1992

\title{
Cross-Transmission Studies with Eimeria arizonensis-like Oocysts (Apicomplexa) in New World Rodents of the Genera Baiomys, Neotoma, Onychomys, Peromyscus, and Reithrodontomys (Muridae)
}

\author{
Steve J. Upton \\ Kansas State University \\ Chris T. McAllister \\ Department of Veterans Affairs Medical Cente \\ Dianne B. Brillhart \\ Kansas State University \\ Donald W. Duszynski \\ University of New Mexico, eimeria@unm.edu \\ Constance D. Wash \\ University of New Mexico \\ Follow this and additional works at: https://digitalcommons.unl.edu/parasitologyfacpubs \\ Part of the Parasitology Commons
}

Upton, Steve J.; McAllister, Chris T.; Brillhart, Dianne B.; Duszynski, Donald W.; and Wash, Constance D., "Cross-Transmission Studies with Eimeria arizonensis-like Oocysts (Apicomplexa) in New World Rodents of the Genera Baiomys, Neotoma, Onychomys, Peromyscus, and Reithrodontomys (Muridae)" (1992). Faculty Publications from the Harold W. Manter Laboratory of Parasitology. 184.

https://digitalcommons.unl.edu/parasitologyfacpubs/184

This Article is brought to you for free and open access by the Parasitology, Harold W. Manter Laboratory of at DigitalCommons@University of Nebraska - Lincoln. It has been accepted for inclusion in Faculty Publications from the Harold W. Manter Laboratory of Parasitology by an authorized administrator of DigitalCommons@University of Nebraska - Lincoln. 


\title{
CROSS-TRANSMISSION STUDIES WITH EIMERIA ARIZONENSIS-LIKE OOCYSTS (APICOMPLEXA) IN NEW WORLD RODENTS OF THE GENERA BAIOMYS, NEOTOMA, ONYCHOMYS, PEROMYSCUS, AND REITHRODONTOMYS (MURIDAE)
}

\author{
Steve J. Upton, Chris T. McAllister ${ }^{\star}$, Dianne B. Brillhart, Donald W. Duszynski†, \\ and Constance D. Wash† \\ Division of Biology, Ackert Hall, Kansas State University, Manhattan, Kansas 66506
}

\begin{abstract}
Cross-transmission experiments were performed using oocysts of an Eimeria arizonensis-like coccidian from Peromyscus leucopus and Peromyscus truei, an E. arizonensis-like coccidian from Reithrodontomys fulvescens, Eimeria baiomysis and Eimeria taylori from Baiomys taylori, Eimeria albigulae from Neotoma albigula, and Eimeria onychomysis from Onychomys spp., between representatives of the above host genera. The $E$. arizonensis-like coccidian from $R$. fulvescens infected Reithrodontomys megalotis, Reithrodontomys montanus, and Peromyscus leucopus. Oocysts of $E$. arizonensis from $P$. leucopus could be transmitted to both $P$. leucopus and $R$. megalotus. Oocysts of E. baiomysis and E. taylori infected only B. taylori. Oocysts of $E$. arizonensis from $P$. truei infected $P$. truei but not Neotoma mexicana or Onychomys leucogaster. Oocysts of $E$. albigulae from $N$. albigula were infective for $N$. mexicana but not for $P$. truei or $O$. leucogaster. Oocysts of $E$. onychomysis from Onychomys spp. infected $O$. leucogaster but not $N$. mexicana or $P$. truei. These results demonstrate that Peromyscus and Reithrodontomys, genera known to be related very closely evolutionarily, are capable of sharing E. arizonensis, whereas morphologically similar coccidians (E. albigulae, E. baiomysis, and $E$. onychomysis) from more distantly related hosts, are probably distinct and more stenoxenous. This also is the first report of coccidians infecting species of Reithrodontomys.
\end{abstract}

Levine et al. (1957) named 10 new species of Eimeria from 52 rodents representing 25 species in 8 genera caught on the north rim of the Grand Canyon, Arizona. Three of these, Eimeria albigulae, Eimeria arizonensis, and Eimeria onychomysis, along with Eimeria baiomysis Levine, Ivens, and Kruidenier, 1958, are similar or indistinguishable morphologically, based on the original descriptions and drawings, even though they were found in rodents of several genera (Levine et al., 1958; Kruidenier et al., 1960). These 4 taxa were given separate specific epithets in the original descriptions, presumably based on the traditional concept that rodent coccidia are highly host specific, at least within a given host genus. Since the original descriptions, published surveys and experimental studies have clouded the boundaries between these forms. For example, E. arizonensis is reported to produce oocysts that differ morphologically in several features (oocyst wall smooth to pitted; number of

Received 26 August 1991; revised 1 November 1991; accepted 1 November 1991.

* Renal Metabolic Laboratory (151-G), Department of Veterans Affairs Medical Center, 4500 South Lancaster Road, Dallas, Texas 75216.

$\dagger$ Department of Biology, The University of New Mexico, Albuquerque, New Mexico 87131. polar bodies; size, shape, texture of oocyst residuum) dependent upon the host in which it is found (Levine et al., 1957; Levine and Ivens, $1960,1963)$. In addition to morphological differences between isolates of $E$. arizonensis from different host species, there are differences also in the electromorph banding patterns between populations of $E$. arizonensis from different host species (Reduker et al., 1987; Wash et al., 1990). Originally described from Peromyscus truei (Shufeldt, 1885), E. arizonensis has been reported since not only to infect rodents of at least 4 other species of Peromyscus but also of Chaetodipus and Dipodomys (Levine et al., 1957; Levine and Ivens, 1960, 1963; Ford et al., 1990). To complicate matters further, most redescriptions of $E$. arizonensis differ enough to suggest there may be multiple species confused as 1 . Given the morphological similarities with the other 3 species, doubt can be cast on their validity as separate species and several questions arise. First, is each form a valid, morphologically similar hostspecific species? If not, do these constitute a single, highly euryxenous species? Or, finally, are some of these valid, host-specific species, whereas others represent more euryxenous forms? The collections and cross-transmission experiments described here attempt to alleviate some of the confusion due the eimerians in murid hosts. 
TABLE I. Wild-caught murid rodents from which oocysts of various Eimeria species were isolated to use in cross-transmission experiments.

\begin{tabular}{|c|c|c|c|c|}
\hline \multirow[b]{2}{*}{ Hosts } & \multicolumn{2}{|c|}{ Collection } & \multirow[b]{2}{*}{ Eimerian isolated } & \multirow{2}{*}{$\begin{array}{l}\text { Primary } \\
\text { isolate } \\
\text { number }\end{array}$} \\
\hline & Locality & Date & & \\
\hline $\begin{array}{l}\text { Reithrodontomys fulvescens } \\
\quad \text { laceyi }\end{array}$ & Hood Co., Texas & April 1988 & $\begin{array}{l}\text { Eimeria arizonensis- } \\
\text { like }\end{array}$ & 1 \\
\hline Baiomys taylori taylori & Dallas Co., Texas & January 1990 & Eimeria taylori & 2 \\
\hline B. t. taylori & Dallas Co., Texas & March 1988 & Eimeria baiomysis & 3 \\
\hline B. t. taylori & Dallas Co., Texas & January 1990 & E. baiomysis & 4 \\
\hline B. t. taylori & Johnson Co., Texas & November 1987 & E. baiomysis & 5 \\
\hline Peromyscus leucopus leucopus & Dallas Co., Texas & April 1988 & E. arizonensis-like & 6 \\
\hline Peromyscus truei truei & Sandoval Co., New Mexico & August 1984 & E. arizonensis-like & 7 \\
\hline Neotoma albigula albigula & Soccoro Co., New Mexico & May 1982 & Eimeria albigulae & 8 \\
\hline Onychomys arenicola $(2)^{*}$ & Hidalgo Co., New Mexico & July 1981 & Eimeria onychomysis & $9^{*}$ \\
\hline Onychomys leucogaster (3)* & Motley Co., New Mexico & May 1980 & E. onychomysis & $9^{*}$ \\
\hline Onychomys torridus (3)* & Hidalgo Co., New Mexico & May 1983 & E. onychomysis & $9^{*}$ \\
\hline
\end{tabular}

* Oocysts from all 8 animals and 3 host species combined as 1 isolate.

\section{MATERIALS AND METHODS}

\section{Natural hosts and primary parasite isolates}

Feces and intestinal contents were collected from wild-caught hosts of 5 genera representing 6 species (Table I). Feces from hosts were placed in separate petri dishes in a thin layer of $2.5 \%(\mathrm{w} / \mathrm{v})$ aqueous potassium dichromate $\left(\mathrm{K}_{2} \mathrm{Cr}_{2} \mathrm{O}_{7}\right)$ and kept at ambient temperature (ca. 21-23 C) for 6-10 days to allow oocysts that were present to sporulate. Eimerians isolated from these naturally infected hosts were used either directly as inocula in cross-transmission experiments or were inoculated into conspecific or congeneric animals to increase oocyst numbers. The resulting pools of oocysts were designated as 15 isolates $(1,1 \mathrm{~A}, 1 \mathrm{~B}, 2,3,4,5,6$, $6 \mathrm{~A}, 7,7 \mathrm{~A}, 8,8 \mathrm{~A}, 9,9 \mathrm{~A}$ ) (Table II). These oocyst isolates/fecal suspensions were stored in refrigerators (4$6 \mathrm{C})$ until they were used in experimental infections. The presumed identity of each isolate, the host from which it was isolated, the recipient host species to which it was transferred experimentally, the age and number of oocysts used as inoculum, and the consequence of each experimental inoculation are given in Table II.

\section{Secondary parasite isolates}

Isolate $1 \mathrm{~A}$ was collected from the feces of 2 adult Reithrodontomys montanus griseus Bailey, 1905, infected with isolate 1 . Isolate $1 \mathrm{~B}$ was derived from the passage of isolate 1A through Reithrodontomys megalotis (Baird, 1858). Isolate 6A came from laboratoryreared Peromyscus leucopus (Rafinesque, 1818) inoculated with isolate 6 . Isolate $7 \mathrm{~A}$ was collected from the feces of 5 laboratory-reared $P$. truei inoculated with isolate 7 . Isolate $8 \mathrm{~A}$ was collected from an adult, wildcaught Neotoma mexicana Baird, 1855, inoculated with isolate 8; prior to inoculation the rodent was maintained in the laboratory for several months and was coccidia-free. Isolate $9 \mathrm{~A}$ came from the feces of 2 coccidia-free Onychomys leucogaster (Wied, 1841), maintained in the laboratory, that were inoculated with isolate 9. Note (Table I) that isolate 9 came from the combined feces of 8 specimens of Onychomys representing 3 species. This was done because all 8 original hosts each had only a very few sporulated oocysts of E. onychomysis.

\section{Morphologic comparisons}

Measurements were made on oocysts and sporocysts of $E$. arizonensis, E. arizonensis-like oocysts, and $E$. baiomysis using an ocular micrometer. All measurements, representing the mean of 30 under a $100 \times$ oil lens, are in micrometers $(\mu \mathrm{m})$ followed by the ranges in parentheses. For $E$. arizonensis isolated from $P$. leucopus, the 30 measurements were taken from 10 oocysts from isolate 6 and 20 were taken from isolate $6 \mathrm{~A}$. For E. arizonensis-like oocysts, 10 oocysts measured were from isolate 1 and 20 were from isolate $1 \mathrm{~A}$. For $E$. baiomysis, 10 oocysts were measured from isolates 3,4 , and 5 each. For E. albigulae and E. onychomysis, the oocysts in these isolates generally conformed to those described by Levine et al. (1957).

\section{Experimental inoculations}

All animals were housed in plastic cages with presterilized wood shavings and given water and commercial rodent mash ad libitum. They were exposed to $12-\mathrm{hr}$ light/dark cycles in rooms maintained ca. 20-23 C. Prior to inoculation, oocysts of an isolate were washed $2-3 \times$ in tap water, counted with a hemacytometer, and then inoculated per os by stomach tube into experimental hosts. Feces from inoculated hosts were collected in 2 ways. For isolates 1 through $6 \mathrm{~A}$, recipient hosts were maintained in plastic cages. On the appropriate days postinoculation (dpi), each animal was picked up, which resulted in its defecating, and these pellets then were examined for oocysts. For isolates 7 through 9A, recipient hosts were placed in wire mesh hanging cages and all feces for each host were collected every $24 \mathrm{hr}$ and examined for oocysts for $20 \mathrm{dpi}$.

Fecal pellets were examined for the presence of oocysts using sucrose flotation (specific gravity 1.30 ) followed by microscopic examination using Nomarski interference-contrast optics. Oocysts were allowed to sporulate in petri dishes in a thin layer of feces/dichromate (see above) and reexamined microscopically 6-10 days later to confirm identification of each coccidian.

Laboratory-reared ICR outbred Mus musculus Linnaeus, 1758, were purchased from Harlan SpragueDawley (Indianapolis, Indiana) and were $2-4$ mo old 
TABLE II. Experimental protocol for inoculation of Eimeria specimens into various rodents.

\begin{tabular}{|c|c|c|c|c|c|c|c|c|}
\hline \multirow{2}{*}{$\begin{array}{l}\text { Isolate } \\
\text { number }\end{array}$} & \multirow[b]{2}{*}{ Eimeria sp. } & \multirow[b]{2}{*}{ Donor host* } & \multicolumn{2}{|c|}{ Recipient* $^{*}$} & \multirow{2}{*}{$\begin{array}{l}\text { Age of } \\
\text { oocysts } \\
\text { (days) }\end{array}$} & \multirow{2}{*}{$\begin{array}{c}\text { Inoculation } \\
\text { dose } \\
\text { (number of } \\
\text { oocysts) }\end{array}$} & \multirow{2}{*}{$\begin{array}{l}\text { Days post- } \\
\text { inoculation } \\
\text { examined }\end{array}$} & \multirow{2}{*}{$\begin{array}{c}\text { Oocysts } \\
\text { present }(+) \\
\text { or absent }(-)\end{array}$} \\
\hline & & & Species & Number & & & & \\
\hline 1 & E. arizonensis & Reithrodontomys fulvescens & R. montanus a & 2 & 330 & 10,000 & $1-20$ & $\begin{array}{c}+ \\
\text { Days 4-14 }\end{array}$ \\
\hline \multirow[t]{3}{*}{$1 \mathrm{~A}$} & E. arizonensis & Reithrodontomys montanus a & R. megalotis $\mathrm{b}$ & 2 & 300 & 2,000 & 5 &,++ \\
\hline & & & P. leucopus $\dagger$ & 2 & 300 & 2,000 & 5 &,++ \\
\hline & & & Mus musculus & 2 & 300 & 2,000 & 5 &,-- \\
\hline \multirow[t]{2}{*}{$1 \mathrm{~B}$} & E. arizonensis & Reithrodontomys megalotis $\mathrm{b}$ & $P$. leucopus & 1 & 168 & 2,000 & 5 & + \\
\hline & & & B. taylori & 1 & 168 & 2,000 & $5,7,9$ & - \\
\hline \multirow[t]{4}{*}{2} & E. taylori & Baiomys taylori & P. leucopus $\dagger$ & 2 & 27 & 2,000 & 5,8 & - \\
\hline & & & R. megalotis & 1 & 27 & 2,000 & 5,8 & - \\
\hline & & & P. leucopus $\ddagger$ & 1 & 167 & 500 & $5,7,9$ &,,--- \\
\hline & & & B. taylori§ & 1 & 167 & 500 & 5,7 &,-+ \\
\hline \multirow[t]{2}{*}{3} & E. baiomysis & B. taylori & P. leucopus & 1 & 725 & 1,500 & 5,8 & - \\
\hline & & & R. megalotis & 1 & 725 & 1,500 & 5 & - \\
\hline 4 & E. baiomysis & B. taylori & P. leucopus & 1 & 13 & 2,000 & 5,8 & - \\
\hline \multirow[t]{2}{*}{5} & E. baiomysis & B. taylori & P. leucopus $\ddagger$ & 1 & 978 & 2,000 & $5,7,9$ &,,--- \\
\hline & & & B. taylori§ & 1 & 978 & 2,000 & 5,7 &,++ \\
\hline 6 & E. arizonensis & Peromyscus leucopus & P. leucopus c & 1 & 461 & 400 & 5,6 &,-+ \\
\hline \multirow[t]{3}{*}{$6 \mathrm{~A}$} & E. arizonensis & P. leucopus c & P. leucopus & 2 & 461 & 400 & 5,6 &,,+++ \\
\hline & & & B. taylori & 1 & 111 & 2,000 & $5,7,9$ &,,--- \\
\hline & & & R. montanus & 1 & 111 & 2,000 & 5,7 &,++ \\
\hline 7 & E. arizonensis & Peromyscus truei & P. truei $\mathrm{d}$ & 5 & $<180$ & 3,000 & $1-20$ & $\begin{array}{c}\text { All + } \\
\text { Days 4-16 }\end{array}$ \\
\hline \multirow[t]{2}{*}{$7 \mathrm{~A}$} & E. arizonensis & P. truei & N. mexicana $\mathrm{e}$ & 1 & $<180$ & 3,000 & $1-20$ & - \\
\hline & & & O. leucogaster $\mathrm{f}$ & 2 & $<180$ & 3,000 & $1-20$ &,-- \\
\hline 8 & E. albigulae & Neotoma albigula & N. mexicana $\mathrm{e}$ & 1 & $<180$ & 3,000 & $1-20$ & $\begin{array}{c}+ \\
\text { Days 3-15 }\end{array}$ \\
\hline \multirow[t]{2}{*}{$8 \mathrm{~A}$} & E. albigulae & Neotoma mexicana & O. leucogaster $\mathrm{f}$ & 2 & $<180$ & 3,000 & $1-20$ &,-- \\
\hline & & & P. truei $\mathrm{d}$ & 5 & $<180$ & 3,000 & $1-20$ & All - \\
\hline 9 & E. onychomysis & Onychomys spp. & O. leucogaster $\mathrm{f}$ & 2 & $<180$ & 3,000 & $1-20$ & $\begin{array}{c}+,+ \\
\text { Days 2-11 }\end{array}$ \\
\hline \multirow[t]{2}{*}{$9 A$} & E. onychomysis & Onychomys leucogaster & N. mexicana $\mathrm{e}$ & 1 & $<180$ & 3,000 & $1-20$ & - \\
\hline & & & P. truei $\mathrm{d}$ & 5 & $<180$ & 3,000 & $1-20$ & All - \\
\hline
\end{tabular}

* Names followed by same letter indicate the same animals.

† Same animals. Inoculated first with isolate $1 \mathrm{~B}$ and then reinoculated 28 days later with isolate 2 .

¥ Same animal. Inoculated with both isolates simultaneously.

$\S$ Same animal. Inoculated with both isolates simultaneously.

at the times of inoculation. Peromyscus leucopus were all $F_{2}$ generation and part of a captive breeding colony at Kansas State University. Feces from the cages of these animals have been checked periodically over the last $2 \mathrm{yr}$ and no coccidian oocyst has ever been seen. The $P$. truei recipients were all $\mathrm{F}_{1}$ generation, laboratory-reared mice derived from the parents from which isolate 7 was obtained. These mice had been checked numerous times before inoculation to assure they were coccidia-free.

To obtain large numbers of isolate 1,2 adult $R$. montanus griseus were collected from Dallas County, Texas. Feces of both animals were checked daily for 14 days prior to inoculation with oocysts of isolate 1 . Following inoculation of these 2 mice, feces were checked daily for unsporulated oocysts to determine prepatent and patent periods. Other specimens of Reithrodontomys used for inoculations were adults collected from Osborne and Pottawatomie counties, Kansas. These mice were placed in individual cages and their feces examined for oocysts at 1,4 , and 11 days postcapture. Inoculations using Kansas mice were at 11 days postcapture.
Baiomys taylori (Thomas, 1887) were $F_{1}$ generation offspring from animals collected from Dallas County, Texas. Mice were 5-10 mo old when used as recipient hosts. Each was placed in a separate cage, and feces were examined daily for 1 wk to assure the absence of extraneous infection prior to its inoculation.

Uninfected control animals could not be used for all inoculation experiments because of the difficulty in obtaining some animals. However, pairs of uninfected $P$. leucopus, housed separately from experimental hosts, were used as controls for experimental inoculations with isolates $1 \mathrm{~A}, 1 \mathrm{~B}, 2$ (167 days), 5, 6, and 6A. An individually housed $R$. megalotis collected in Kansas also was used as a control during inoculation of isolate 1A. One B. taylori, a littermate of the other pygmy mouse used, served as control for inoculations with isolates 2 (167 days) and 5. For controls, feces were examined, as above, on the same day(s) that experimentally infected hosts were examined.

Voucher specimens of rodents are deposited in either the Arkansas State University Museum of Zoology, the Texas Tech University Museum, or in the University of New Mexico Museum of Southwestern Biology. 
TABLE III. Measurements of oocyst features of Eimeria species collected from Peromyscus leucopus, species of Reithrodontomys, and Baiomys taylori.*

\begin{tabular}{lccc}
\hline & & Oocyst source & \\
\cline { 2 - 4 } \multicolumn{1}{c}{ Parameter } & Baiomys taylori & Peromyscus leucopus & Reithrodontomys spp. \\
\hline Oocyst size & $24.3 \times 20.0$ & $24.3 \times 19.8$ & $24.1 \times 20.2$ \\
& $(20-30 \times 17-24)$ & $(21-27 \times 17-22)$ & $(20-30 \times 17-26)$ \\
Oocyst SI $\dagger$ & 1.2 & 1.2 & 1.2 \\
& $(1.1-1.3)$ & $(1.1-1.4)$ & $(1.1-1.5)$ \\
Oocyst residuum (OR) diameter & 7.0 & 8.3 & 8.2 \\
& $(6-9)$ & $(7-10)$ & $(4-12)$ \\
Number OR globules & $1-10$ & $1-50$ & $1-30$ \\
Oocyst outer walls & Light-moderate pitting & Smooth-moderate pitting & Smooth-moderate pitting \\
Polar granuleł & 2.0 & 2.1 & 2.3 \\
& $(1-3)$ & $(2-3)$ & $(2-3)$ \\
Sporocyst size & $11.9 \times 8.2$ & $11.4 \times 7.8$ & $11.4 \times 7.9$ \\
& $(10-14 \times 7-9)$ & $(11-13 \times 7-9)$ & $(10-14 \times 7-9)$ \\
Sporocyst SI $\dagger$ & 1.45 & 1.5 & 1.5 \\
& $(1.3-1.6)$ & $(1.3-1.6)$ & $(1.3-1.55)$ \\
Stieda body size & $1.6 \times 2.8$ & $1.6 \times 2.4$ & $1.5 \times 2.6$ \\
(height $\times$ width) & $(1-2 \times 2-4)$ & $(1-2 \times 2-3)$ & $(1-2 \times 2-3)$ \\
Sporozoite size $\$$ & $15.8 \times 3.4$ & $14.0 \times 3.2$ & $14.6 \times 3.2$ \\
& $(14-18 \times 3-4)$ & $(11-17 \times 3-4)$ & $(13-18 \times 3-3.4)$ \\
Refractile body size & $5.5 \times 3.0$ & $6.3 \times 3.2$ & $5.9 \times 3.1$ \\
& $(5-6 \times 2.8-3.2)$ & $(5-8 \times 2-4)$ & $(5-7 \times 3-4)$ \\
\hline
\end{tabular}

* Measurements are means in micrometers $(n=30)$ with ranges in parentheses.

† SI, shape index (length/width).

$\ddagger$ Long axis measurement.

$\S$ Size in situ.

\section{RESULTS}

Oocysts we isolated from hosts of 5 genera, Baiomys, Neotoma, Onychomys, Peromyscus, and Reithrodontomys, were morphologically similar to those of $E$. arizonensis, described originally from species of Peromyscus. Detailed structural comparisons were made among 3 of our isolates from 3 closely related hosts (Table III), and photomicrographs of isolates from each genus can be compared in Figures 1-15.

Sporocysts were lemon-shaped, with globular oocyst residua (either homogeneous or fragmented), and usually 1 (but up to 4) polar granule(s) was present. Stieda bodies were prominent, sub- and parastieda bodies absent, and sporozoites each possessed a large, posterior refractile body, but no anterior body. The only notable difference was that the Stieda body associated with sporocysts of $E$. baiomysis was more flattened than those on sporocysts from specimens of Peromyscus, Neotoma, or Reithrodontomys (cf. Figs. 1, 4, 10 vs. 9).

Isolate 1, from Reithrodontomys fulvescens $\mathbf{J}$. A. Allen, 1894, was transmissible to $R$. megalotis, $R$. montanus griseus, and $P$. leucopus but not to $M$. musculus or $B$. taylori. Isolate $3, E$. baiomysis, readily infected $B$. taylori but not $P$. leucopus or $R$. megalotis. McAllister and Upton (1988) reported a morphologically dissimilar coccidian, Eimeria taylori McAllister and Upton, 1988 , to infect $P$. leucopus as well as $B$. taylori. However, it too was not infective for $P$. leucopus or $R$. megalotis. Isolate $6, E$. arizonensis from $P$. leucopus, was infective for $2 P$. leucopus and for $1 R$. megalotis but not for B. taylori. Isolate $7, E$. arizonensis from $P$. truei, was infective for $P$. truei but not for $N$. mexicana or $O$. leucogaster. Isolate $8, E$. albigulae from $\mathrm{Ne}$ otoma albigula Hartley, 1894, was infective for $N$. mexicana but not for $O$. leucogaster or $P$. truei. Isolate $9, E$. onychomysis combined from 8 specimens representing 3 species of Onychomys, was infective for $O$. leucogaster but not for N. mexicana or P. truei.

\section{DISCUSSION}

Dogma dictates that eimerians are highly host specific, being limited naturally to a narrow range of host species, usually congenerics or, less frequently, only to conspecifics (Marquardt, 1973; Joyner, 1982). However, during the last 2 decades, there have been both cross-transmission studies (Todd and Hammond, 1968a, 1968b; de Vos, 1970; Mayberry and Marquardt, 1973; Mayberry et al., 1982) and observations from wild-caught rodents (Vance and Duszynski, 1985; Hill and Duszynski, 1986; McAllister and Upton, 1988; Ford et al., 1990) that suggest some 

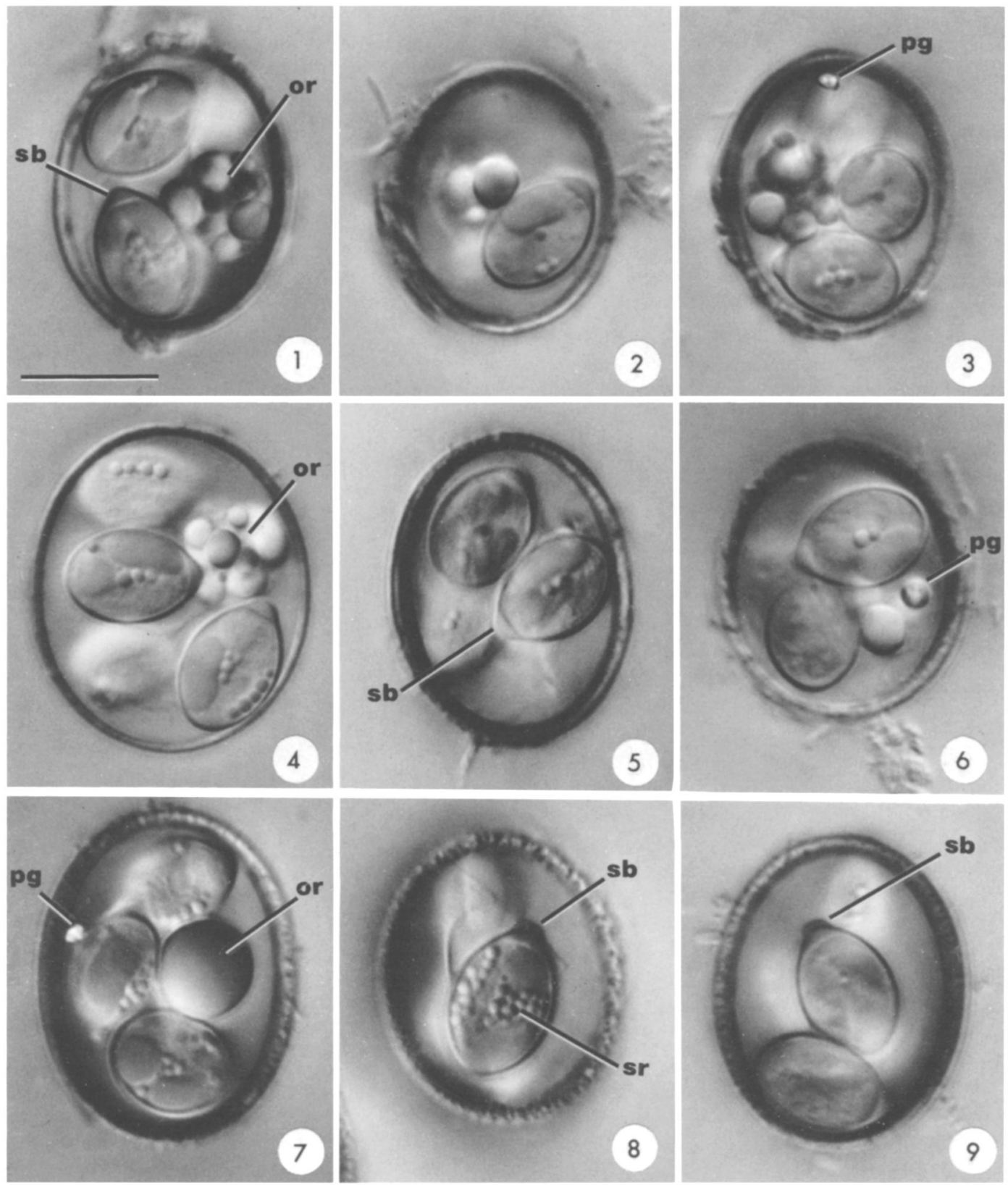

FIGURES 1-9. Nomarski-interference contrast photomicrographs of sporulated oocysts of various Eimeria species from rodents. 1-3. Eimeria arizonensis from Peromyscus leucopus. 4-6. Eimeria arizonensis from Reithrodontomys fulvescens. 7-9. Eimeria baiomysis from Baiomys taylori. Scale bar $=10 \mu \mathrm{m}$ for all figures. Abbreviations: or, oocyst residuum; pg, polar granule; sb, Stieda body; sr, sporocyst residuum.

rodent coccidians are more general in their host requirements and may be able to infect animals in several genera or even in different families.

When working with coccidians from wild animals, the problem of correctly identifying the coccidians found is compounded by the fact that some species seem to exhibit a great deal of phenotypic plasticity in the structure of their sporulated oocysts, not only among and within host species, but also in oocysts from the same host (e.g., Parker and Duszynski, 1986; Gardner and Duszynski, 1990). A similar situation occurs in 

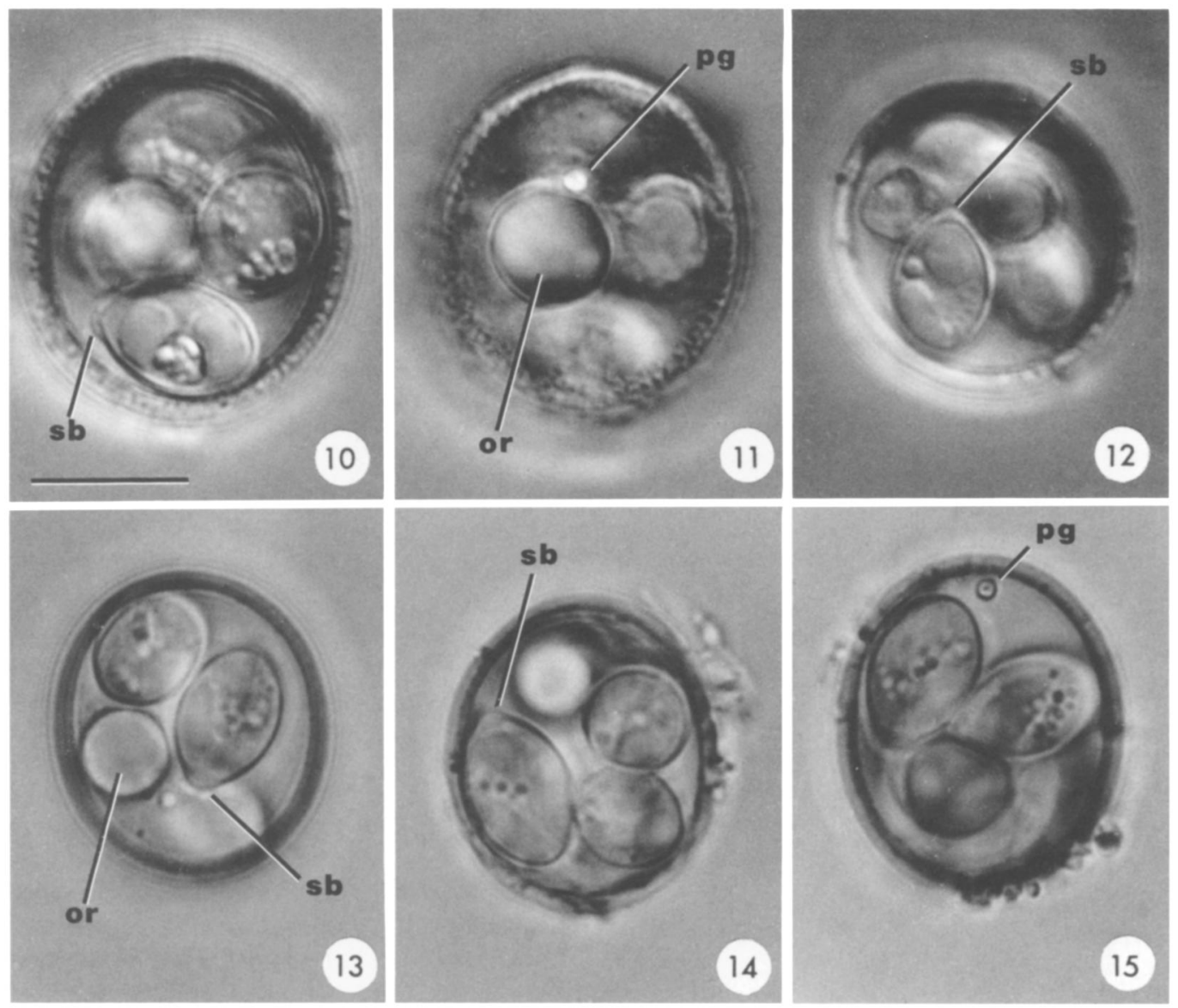

FIGURES 10-15. Nomarski-interference contrast photomicrographs of sporulated oocysts of various Eimeria species from rodents. 10-12. Eimeria albigulae from Neotoma albigula. 13-15. Eimeria onychomysis from Onychomys leucogaster. Scale bar $=10 \mu \mathrm{m}$ for all figures. Abbreviations: or, oocyst residuum; pg, polar granule; $\mathrm{sb}$, Stieda body.

1 of the most ubiquitous coccidians found in murid rodents, $E$. arizonensis. Oocysts of this form were said to be "composed of a single smooth layer, lined by a thin membrane"; they also usually had "a single large, clear, colorless residual globule, about $3.6 \mu \mathrm{m}$ in diameter" (Levine et al., 1957). Later, Levine and Ivens (1960) reported E. arizonensis from species of Peromyscus in Illinois. In P. maniculatus the oocyst wall was described as "slightly to moderately pitted" and the oocyst residuum as a "cluster of large, homogeneous granules/globules"; whereas in P. leucopus in Illinois, the oocysts had walls that were "sometimes smooth, but usually more or less pitted" with oocyst residua of "a single large, waxy-appearing globule about 4." Reduker et al. (1985), surveying species of Peromyscus from the southwestern U.S.A. and northern
Mexico, found E. arizonensis-like oocysts in 41 of 102 (40\%) specimens of Peromyscus (Peromyscus eremicus (Baird, 1858), Peromyscus maniculatus (Wagner, 1845), P. truei) and provided a "combined" redescription based on measurements/observations of nearly 500 sporulated oocysts. These observations lead to the conclusion that $E$. arizonensis is not exceptionally species specific and that it is a highly polymorphic form similar to Eimeria opimi described from South American fossorial rodents (Gardner and Duszynski, 1990). This may be true, but the possibility also exists that the variation seen in sporulated oocysts of $E$. arizonensis actually represents several isolates of 1 species or several species that are morphologically similar.

Finally, to further complicate an answer to the question, "What is the real E. arizonensis?" sev- 
eral species of coccidia described from murid rodents are reported to have sporulated oocysts that are nearly identical to those of $E$. arizonensis; among these are E. albigulae from $N$. albigu$l a, E$. baiomysis from $B$. taylori, and E. onychomysis from $O$. leucogaster. Unfortunately, the descriptions of these forms are inadequate by today's standards and only line drawings exist in the original descriptions; there is no original published photograph or phototype on deposit with any accredited national museum (see Bandoni and Duszynski, 1988), so that oocysts representing the original forms seen cannot be compared directly.

In an attempt to help unravel the mystery of $E$. arizonensis, we did some initial cross-transmission studies using $E$. arizonensis-like oocysts from various hosts and passed them to other hosts. Our results must be interpreted cautiously, given the shortcomings of the experimental design. These results suggest the following: Eimeria arizonensis-like oocysts are capable of infecting a broad range of hosts in at least 2 genera, Peromyscus and Reithrodontomys. Although these data are in contrast to the traditional concept of species or genus specificity among the coccidia, it is not surprising given that these genera are closely related evolutionarily (Hooper and Musser, 1964; Carlton, 1980). On the other hand, oocysts of E. albigulae, E. baiomysis, and $E$. onychomysis, all structurally similar to $E$. arizonensis, appear to be separate species, at least based on the limited number of recipient animals we used and the fact that some of them had to be reinoculated with different forms/species at different times during their captivity. These results also suggest that $E$. arizonensis-like oocysts reported by Ford et al. (1990) from heteromyids of the genera Chaetodipus and Dipodomys are most likely not $E$. arizonensis. In addition, we speculate that should $E$. arizonensis-like oocysts be recovered from golden mice, Ochrotomys nuttalli (Harlan, 1832), they most likely will represent the same parasite species found in species of Peromyscus and Reithrodontomys. Golden mice are considered the closest living relative to Peromyscus species (Carlton, 1980).

Although the oocysts of $E$. albigulae (see Reduker and Duszynski, 1985: figs. 1, 2) and $E$. arizonensis from species of Peromyscus and Reithrodontomys (Figs. 1-6) are indistinguishable, our modest cross-transmission experiments suggest they are host-specific forms. Also, oocysts we isolated from $O$. leucogaster appear only to be infective for $O$. leucogaster. We are aware, however, that other factors (e.g., unknown immune status of our recipients) may have influenced the negative results we saw, and that just because a few recipient hosts do not become infected does not necessarily mean that under natural conditions, where millions of random crosstransmission events take place between hosts that occupy similar space and time, that such successful host transfers could not occur.

Oocysts of $E$. baiomysis, although also morphologically similar to those of $E$. arizonensis, have Stieda bodies that are slightly more flattened (cf. Figs. 1-6 vs. Figs. 7-9). Our transmission experiments further suggest that the 2 are distinct species. In addition, the transmission studies between specimens of Baiomys and Peromyscus suggest that the report of $E$. taylori in $P$. leucopus was a misidentification (McAllister and Upton, 1988). It appears likely that these oocysts in P. leucopus were those of Eimeria langebarteli Ivens, Kruidenier, and Levine, 1959. Thus, even though $B$. taylori is considered a close relative of $P$. leucopus, our results are consistent with the genetic analysis by Yates et al. (1979) that suggests both genera are less closely related than are Reithrodontomys and Peromyscus.

\section{ACKNOWLEDGMENTS}

Collections in Kansas were under permits 88122 , SC-055-89, and SC-046-90 from the Kansas Department of Parks and Wildlife to S.J.U. C.T.M. thanks the Texas Parks and Wildlife Department for Scientific Collecting Permit SPR0390-027, personnel of Georges Creek and Russell ranches for allowing collecting on their properties, and J. T. McAllister, III, for assistance with collecting. This study also was partly supported by NIH-DHHS grant 5 SO6, RR-0813907 to the University of New Mexico (D. W. Duszynski and T. L. Yates).

\section{LITERATURE CITED}

BANDONI, S. M., AND D. W. DuszYNSKI. 1988. A plea for improved presentatiion of type material for coccidia. An invited critical comment. Journal of Parasitology 74: 519-523.

Carlton, M. D. 1980. Phylogenetic relationships in neotomine-peromyscine rodents (Muroidea) and a reappraisal of the dichotomy within New World Cricetinae. Miscellaneous Publications of the $\mathrm{Mu}$ seum of Zoology, University of Michigan 157: 1146.

DE VOS, A. J. 1970. Studies on the host range of Eimeria chinchillae de Vos and Van der Westhui- 
zen, 1968. Onderstepoort Journal of Veterinary Research 37: 29-36.

FORD, P. L., D. W. DUSZYNSKI, AND C. T. MCALLISTER. 1990. Coccidia (Apicomplexa) from heteromyid rodents in the southwestern United States, Baja California, and northern Mexico with three new species from Chaetodipus hispidus. Journal of Parasitology 76: 325-331.

GARDNeR, S. L., AND D. W. DuszYNSKI. 1990. Polymorphism of eimerian oocysts can be a problem in naturally infected hosts: An example from subterranean rodents in Bolivia. Journal of Parasitology 76: 805-811.

Hill, T. P., AND D. W. Duszynski. 1986. Coccidia (Apicomplexa: Eimeriidae) from sciurid rodents (Eutamias, Sciurus, Tamiasciurus spp.) from the western United States and northern Mexico with descriptions of two new species. Journal of Protozoology 33: 282-288.

HoOPER, E. T., AND G. G. MusSer. 1964. The glans penis in neotropical cricetines (family Muridae) with comments on classification of muroid rodents. Miscellaneous Publications of the Museum of Zoology, University of Michigan 123: 1-57.

JOYNER L. P. 1982. Host and site specificity. In The biology of the coccidia, P. L. Long (ed.). University Park Press, Baltimore, Maryland, p. 35-62.

Kruidenier, F. J., N. D. LeVINE, AND V. IVENS. 1960. Eimeria (Protozoa: Eimeriidae) from the rice rat and pygmy mouse in Mexico. Transactions of the Illinois Academy of Sciences 52: 100-101.

LEVINE, N. D., AND V. Ivens. 1960. Eimeria and Tyzzeria (Protozoa: Eimeriidae) from deermice (Peromyscus spp.) in Illinois. Journal of Parasitology 46: 207-212.

—, AND —. 1963. Eimeria siniffi sp. n. and E. arizonensis (Protozoa: Eimeriidae) from deermice in British Columbia. Journal of Parasitology 49: 660-661.

- AND F. J. KrUidenier. 1957. New species of Eimeria from Arizona rodents. Journal of Protozoology 4: 80-88.

- , AND - 1958. New species of Eimeria (Protozoa: Eimeriidae) from Mexican rodents. Transactions of the Illinois Academy of Sciences 50: 291-298.

MARQUARDT, W. C. 1973. Host and site specificity. In The coccidia, D. M. Hammond and P. L. Long (eds.). University Park Press, Baltimore, Maryland, p. 23-43.

MayberRy, L. F., and W. C. Marquardt. 1973. Transmission of Eimeria separata from the normal host, Rattus, to the mouse, Mus musculus. Journal of Parasitology 59: 198-199. $\longrightarrow,-$ D. J. Nash, and B. Plan. 1982. Genetic dependent transmission on Eimeria separata from Rattus to three strains of Mus musculus, an abnormal host. Journal of Parasitology 68: 11241126.

MCAllister, C. T., AND S. J. Upton. 1988. Eimeria taylori n. sp. (Apicomplexa: Eimeriidae) and $E$. baiomysis from the northern pygmy mouse, Baiomys taylori (Rodentia: Cricetidae), from Texas, U.S.A. Transactions of the American Microscopical Society 107: 296-300.

Parker, B. B., AND D. W. Duszynski. 1986. Polymorphism of eimerian oocysts: A dilemma posed by working with some naturally infected hosts. Journal of Parasitology 72: 602-604.

Reduker, D. W., AND D. W. DusZyNSKI. 1985. Eimeria ladronensis $\mathrm{n}$. sp. and E. albigulae (Apicomplexa: Eimeriidae) from the woodrat, Neotoma albigula (Rodentia: Cricetidae). Journal of Protozoology 32: 548-550.

,,- AND T. L. YATES. 1987. Evolutionary relationships among Eimeria spp. (Apicomplexa) infecting cricetid rodents. Canadian Journal of Zoology 65: 722-735.

- L. A. Hertel, AND D. W. Duszynski. 1985. Eimeria spp. (Apicomplexa: Eimeriidae) infecting Peromyscus rodents in the southwestern United States and northern Mexico with descriptions of two new species. Journal of Parasitology 71: 604613.

Todd, K. S., JR., AND D. M. Hammond. 1968a. Life cycle and host specificity of Eimeria callospermophili Henry, 1932 from the Uinta ground squirrel Spermophilus armatus. Journal of Protozoology 15: 1-8.

- AND - 1968b. Life cycle and host specificity of Eimeria larimerensis Vetterling, 1964, from the Uinta ground squirrel Spermophilus armatus. Journal of Protozoology 15: 268-275.

VANCE, T. L., AND D. W. DUSZYNSKI. 1985. Coccidian parasites (Apicomplexa: Eimeriidae) of Microtus spp. (Rodentia: Arvicolidae) from the United States, Mexico, and Japan with descriptions of five new species. Journal of Parasitology 71: 302-311.

Wash, C. D., D. W. Duszynski, and T. L. Yates. 1990. Enzyme variation of Eimeria arizonensis from Peromyscus truei and P. boylii. Journal of Protozoology 37: 536-540.

YATES, T. L., R. J. BAKeR, AND R. K. BARNetT. 1979. Phylogenetic analysis of karyotypic variation in three genera of peromyscine rodents. Systematic Zoology 28: 40-48. 